\title{
INDIVIDUAL VALUES, EMPLOYMENT CHARACTERISTICS AND THE ETHICAL CLIMATE IN TOURISM
}

\author{
Maja Mijatov \\ Aleksandra S. Dragin \\ Antonio Badurina
}

https://doi.org/10.20867/tosee.05.41

\begin{abstract}
Purpose - The ethical climate represents the employees' perception of standards and norms of acceptable behaviour within the organization. However, the ethical climate might be shaped by the employees' individual values, such as security, self-respect, being well-respected, self-fulfillment, sense of belonging, excitement, fun and enjoyment, good inerpersonal relationships and the sense of accomplishment. On the other hand, employment characteristics, such as employment on the seasonal basis or throughout the whole year, full or modified working hours and the length of the employees' working tenure, could also shape the ethical climate perception. Accordingly, this research was aimed at identifying the impact of individual values and selected employment characteristics on perception of the ethical climate among the employees in hotels of Kopaonik, popular tourism destination of Serbia.

Methodology - This survey research started in Kopaonik in 2013 and it was continued until the 2015. It was conducted on the sample of 211 hotel employees. Collected data were analysed by using the Statistical Programme for Social Sciences, in order to identify the influence of individual values and employment characteristics on the ethical climate perception.

Findings - The research results pointed out that four out of nine individual values (sense of belonging, good interpersonal relations, self-fulfilment, being well respected) shape the employees' perception of certain ethical climate types, together with the working status and the working tenure of the employees. Further research might be oriented towards different countries in order to identify similarities and differences between results gained in this research, conducted within transitional society, comparing to the countries considered as developed in terms of economy and ethical standards.

Contributions - Besides theoretical contributions, the research results might have practical implication, due to the fact that the awareness on the employees' individual values, together with providing the adequate conditions related to their employment, could encourage the positive ethical climate, while, in opposite, it could cause different negative outcomes for general business performances.
\end{abstract}

Keywords ethical climate, hotel employees, individual values, organizational characteristics, human resource management

\section{INTRODUCTION}

Ethical climate is important aspect of business ethics and it encompasses the employees' perception of what is considered as ethical in the business environment of particular organization. It refers to "the common perceptions of the employees regarding behaviour that is considered as ethically correct and the manner in which the ethical issues and 
ToSEE - Tourism in Southern and Eastern Europe, Vol. 5, pp. 441-455, 2019

M. Mijatov, A. S. Dragin, A. Badurina: INDIVIDUAL VALUES, EMPLOYMENT ...

problems in the organization should be resolved" (Victor and Cullen 1987: 101). However, perception of the ethical climate might differ (Authors 2019; Authors, In Press; Authors, In Review; Huimin and Ryan 2011; Kim and Miller 2008; Lee and Tsang 2013), on the basis of the employees' individual characteristics (Kim and Miller 2008; Quazi 2003), but also the characteristics of their employment (Brown and Treviño 2006; Brown et al. 2005; Koh and Boo 2001; Lucas 2000; Petrick and Quinn 2001; Schwartz 2001; Treviño et al. 2003).

Individual moral identity, or a tendency towards certain individual values, determines when, why and whether the individuals behave ethically, in order to achieve the interests of the collective, such as organizations, communities or the whole society (Nasir and Kirshner 2003). Therefore, individual moral identity represents specific construction of moral values that employees are striving to, which could further be reflected on perception of ethics and individual behaviour (Aquino and Reed 2002; Bergman 2002).

However, as already mentioned, the employees' attitudes and their behaviour could not be influenced only by their individual values, but also by the various employment characteristics (Cullen et al. 2003; Elci and Alpkan 2009; Koh and Boo 2001; Luria and Yagil, 2008; Schminke et al. 2005; Schulte et al. 2006; Victor and Cullen 1988; Weeks et al. 2004).

Although there are several studies exploring the ethical climate within tourism industry (Kim and Miller 2008; Luria and Yagil 2008; Zoghbi-Manrique-de-Lara and GuerraBaez 2016), it could be said that it has not been sufficiently researched, especially in Serbia and similar societies in transition, where standards of ethical behaviour are constantly changing.

One of the first studies of the ethical climate in Serbian tourism industry was conducted by the Authors (2019). Within this research, five ethical climate types were identified and these ethical climate types were labelled as: Instrumental (providing the organizational interest), Efficiency (gaining the business efficiency), Individual norms (behaving in respect to the personal sense of what is right or wrong), Team spirit (care for the colleagues' good) and Adhering the rules (organizational expectations focused on abiding the prescribed rules by its employees). Another study dealing with the ethical climate in tourism of Serbia was conducted by the Authors (In Review), which was actually a part of the bigger study (Authors 2019). Authors (In Review) researched the influence of individual values and selected organizational characteristics on perception of previously identified ethical climate types in tourism sector of Serbia, on the sample of those employed in travel agencies, hotels, restaurants, museums and tourism organizations. However, previous research related to the ethical climate showed that it could vary on the basis of the organization type, which means that perception of this construct could also be distinguished within the organizations of different types operating in the same sector, as indicated by Victor and Cullen $(1987,1988)$, who mostly determined the manner in which the ethical climate is researched nowadays. Accordingly, this research was aimed at identifying the impact of individual values and selected employment characteristics on perception of the ethical climate among the employees in hotels of Kopaonik, popular tourism destination of Serbia. It is a destination that is intensively focused on the market segments with higher incomes, which is the 
ToSEE - Tourism in Southern and Eastern Europe, Vol. 5, pp. 441-455, 2019

M. Mijatov, A. S. Dragin, A. Badurina: INDIVIDUAL VALUES, EMPLOYMENT ...

main reason why it is expected that work with the human resources is highly developed within Kopaonik, so this destination could be considered as suitable for research dealing with the employees' perception of the ethical climate.

\section{LITERATURE REVIEW}

\section{Ethical climate}

As already mentioned, the ethical climate represents the employees' perception and it is related to their beliefs about standards and norms of acceptable behaviour (Cullen et al. 2003; Victor and Cullen 1987). Thus, not only that ethical climate represents the official rule and control system of the organization, it also represents an important aspect of the business that could influence the employees' behaviour (Lee et al. 2015).

Victor and Cullen $(1987,1988)$ developed theoretical typology of the ethical climate. According to their theory, there are nine theoretical types of the ethical climate. Three of these ethical climate types are egoistic and they are oriented towards self-interest, company profit or efficiency. Furthermore, there are also three benevolence ethical climate types, oriented towards friendship, team interest or social responsibility. Finally, three ethical climate types might be principled, or more precisely oriented towards personal morality, company rules and procedures or the law and professional codes (Victor and Cullen 1987, 1988).

The ethical climate is considered as relevant for service activities, as it might improve a contact between the customers and service providers (Kim and Miller 2008; Luria and Yagil 2008; Schneider et al. 2000; Zoghbi-Manrique-de-Lara and Guerra-Baez 2016). It is, therefore, important to identify the ethical climate types, represented within the organization (Victor and Cullen 1987, 1988).

\section{Individual values}

Due to the fact that individual values often represent a central part of one's life, it could also be said that these values might shape the employees' attitudes and behaviour. However, everyone could strive to different values and this could also be reflected in differences among the attitudes and behaviours (Kahle 1983).

Results of the research conducted by the Authors (In Review), based on the sample divided into the sub-samples of the managers and employees within the lower organizational levels, indicated that managers who consider the sense of belonging as important individual value pointed the greatest perception of Individual norms. On the other hand, perception of Individual norms is the lowest among the managers who consider that sense of belonging does not represent an important individual value (Authors, In Review). 
ToSEE - Tourism in Southern and Eastern Europe, Vol. 5, pp. 441-455, 2019

M. Mijatov, A. S. Dragin, A. Badurina: INDIVIDUAL VALUES, EMPLOYMENT ...

Furthermore, results of the same research showed that perception of Efficiency is lower among the managers with pronounced sense of fun and enjoyment in life. These results are not surprising, due to the fact that efficiency and fun are the opposite constructs (Authors, In Review).

Also in the case of the managers in tourism, perception of Individual norms is increasing along with importance of good inerpersonal relationships. Those who consider good inerpersonal relationships as important individual value, will consider their organization as a friendly-oriented institution, where employees have the freedom to manage their own ethics in business (Authors, In Review).

The level of self-fulfilment among the company managers influences their perception of Individual norms and Team spirit. It is interesting that the highest level of perception of Individual norms and Team spirit is identified for the managers who emphasize that they are undecided regarding the importance of self-fulfilment. This could mean that these managers highly appreciate the self-fulfilment, but also consider that it is socially unacceptable to recognize it (Authors, In Review).

Similar undecided attitude managers showed when evaluating the sense of being well respected by the others, which shaped their perception of Instrumental and Efficiency. Thus, undecided managers have the greatest perception of Instrumental and the same goes for Efficiency (Authors, In Review). Authors (In Review) pointed out that undecided managers are an interesting category, due to their unwillingness to define their own personal attitude.

Finally, results concerning the impact of individual values on perception of the ethical climate among the employees within the lower organizational levels indicated the impact of sense of belonging and security. Thus, sense of belonging could affect their perception of Adhering the Rules. Throughout the fulfilment of organizational expectations regarding the compliance with the rules, employees within the lower organizational levels might have a greater chance of gaining the sense of belonging to the organization itself. Also, it is important to note that almost everyone consider the sense of security as important and very important individual value. This value positively influenced their perception of Efficiency (Authors, In Review).

Thus, individual values could shape the employees' perception, but also their behaviour. However, these characteristics are not sufficient for detailed explanation of the perception of ethics and behaviour itself, which is the main reason why it is necessary to consider the other aspects, such as organizational characteristics, including the characteristics of employment (Schulte et al. 2006).

\section{Employment characteristics}

Tourists' movements are mostly related to certain season, which imposes seasonality as one of the main characteristic of tourism business. Seasonal operations are characteristic for business units that are operating during the certain part of the year, while remaining time they are out of function. This type of the business causes one of the biggest problems of tourism, represented in the form of necessity for engaging the seasonal workforce 
(McCuddy et al. 2010). This problem does not go beyond Kopaonik, due to the fact that it is also seasonal tourism destination, that employs numerous seasonal workers from different parts of Serbia during the winter season (December-April). Hotels within this destination are mostly out of service in the period before and after the winter season, or they operate during the whole year, but with reduced number of human resources throughout the off-season, so it is necessary to research the manner in which this fact might be reflected on the employees' perception of the ethical climate (Pinar et al. 2011).

Additionally, employment status could also be considered depending on whether the employees are working full-time, or shorter in their working shifts. Previous research pointed out that full-time employees have higher perception of Personal interest and Law and codes and lower perception of Moral care, compared to the half-time employees. Tilly (1992) pointed out that managers often find that part-time employees have less experience, lower levels of competence, ethical standards and commitment to their working tasks and the whole company. It is also considered that seasonal workforce might show lower level of ethical behaviour comparing to the employees working throughout the whole year, due to their uncertainty or lack of will to continue the career development in specific business environment after the end of tourism season (Jolliffe and Farnsworth 2003; McCuddy et al. 2010; Pinar et al. 2011).

Finally, the research that examined the impact of length of working tenure on perception of the ethical climate showed that employees with less than one year of working tenure are distinguished by the highest level of Moral care, the average level of Law and code and the lowest level of Personal interest. On the other hand, employees who have between one and three years of service experience pointed low perception of Moral care, the highest level of Personal interest and the lowest level of Law and code (Kim and Miller 2008). Furthermore, previous research showed that longer working tenure might cause the stronger employees' attitudes on the ethical issues (Victor and Cullen 1988).

\section{METHODOLOGY}

Presentation of the research instrument is followed by an explanation of the procedure of data collecting. In the end of the methodological part, the main characteristics of the sample are represented.

\section{Instrument}

The List of individual values developed by Kahle (1983) was adopted for the purpose of this research. This List obtains nine individual values represented in the form of security, self-respect, being well-respected, self-fulfillment, sense of belonging, excitement, fun and enjoyment, good inerpersonal relationships and sense of accomplishment (Kahle, 1983).

In addition to the List of individual values, respondents answered the questions related to the main characteristics of their employment, such as whether they work on a seasonal basis or throughout the whole year, full or modified working hours (such as: half-time, 
ToSEE - Tourism in Southern and Eastern Europe, Vol. 5, pp. 441-455, 2019

M. Mijatov, A. S. Dragin, A. Badurina: INDIVIDUAL VALUES, EMPLOYMENT ...

full-time, employment on the basis of the pupils' or students' practice, $7 \mathrm{~h}$ ), including the length of their working tenure.

Other segment of the questionnaire was related to the ethical climate. This segment obtained Victor and Cullen's Ethical Climate Questionnaire (with 26 items). Gained answers regarding the employees' individual values, as well as the main characteristics of their employment were analysed in the context of their influence on shaping the employees' perception of pre-identified, already defined, types of the ethical climate in hotels in Kopaonik: Law and care, Adhering the law, procedures and rules, Organizational interest, Team spirit and personal morality and Personal interest (Authors, In Press).

\section{Procedure}

This survey research started in Kopaonik in 2013 and it was continued until the 2015. Authors collected the data by using the standard pen-and-paper procedure. Total sample of 211 respondents from $70.59 \%$ of hotel facilities in Kopaonik was collected. Authors distributed 300 questionnaires to the respondents. However, 236 questionnaires were returned to the authors, while 211 were completely fulfilled and taken into the consideration.

\section{Sample}

About $52.6 \%$ of the respondents were male, while $47.4 \%$ of them were female. Majority of the respondents belongs to the age group between 21 and 30 years $(49.8 \%)$ and the most frequent degree of education within the sample is high school (63.5\%). Employees' education mostly comes out of tourism $(83.4 \%)$. Based on the characteristics of the employment, it could be seen that most of the respondents, even $74.9 \%$ of the entire sample, work in Kopaonik exclusively during the winter season. Employees mostly gained the information regarding the open job positions on the basis of their personal contacts with those who already worked in Kopaonik. Majority of the respondents, $82.5 \%$ of them, are full-time employees, but it could also be noted that most of the respondents have up to 5 years of working tenure $(54.5 \%)$. The short working tenure of the respondents is not surprising, due to the fact that respondents are mostly young people, at the beginning of their professional career development.

\section{RESEARCH RESULTS}

The research results pointed out that four out of nine individual values shape the employees' perception of certain ethical climate types (Table 1). Thus, perception of Team spirit and personal morality is influenced by the sense of belonging. The highest perception of Team Spirit and personal morality is recorded among the employees who always consider the sense of belonging as important. The lowest perceptions of this ethical climate type are recorded among the employees who never consider the sense of belonging as important. It could be concluded that perception of Team spirit and personal morality is growing along with an increase of importance of sense of belonging among the employees. 
ToSEE - Tourism in Southern and Eastern Europe, Vol. 5, pp. 441-455, 2019

M. Mijatov, A. S. Dragin, A. Badurina: INDIVIDUAL VALUES, EMPLOYMENT ...

Furthermore, it is identified that sense of good interpersonal relations shaped the employees' perception of Personal interest. Thus, the highest perception of Personal interest is identified for the employees who never consider good interpersonal relations as important. The lowest perception of this ethical climate type, on the other hand, is obtained for the employees who often consider good interpersonal relationship as important. It could be seen that perception of Personal interest is actually decreasing along with an increase of the importance of good interpersonal relations among the employees.

Perception of Adhering the law, procedures and rules is under the influence of the sense of self-fulfilment for the employees (Table 1). Thus, the highest perception of this ethical climate type is identified among the employees who never consider the self-fulfilment as important. On the other hand, the lowest perception of Adhering the law, procedures and rules is shown by the employees who emphasize that sense of self-fulfilment is rarely important to them. It could be noticed that perception of Adhering the law, procedures and rules is low among the employees whose sense of self-fulfilment is not so important, while it is rising among those who consider self-fulfilment as important.

Individual value designated as the tendency of the employees to be well respected shapes their perception of Organizational interest (Table 1). Based on the research results, it could be seen that perception of Organizational interest is growing along with a decrease in importance that employees attach to the sense of being well respected by the others.

\section{Table 1: General Linear Models, ethical climate and individual values}

\begin{tabular}{|c|c|c|c|c|c|c|}
\hline \multirow{2}{*}{\multicolumn{2}{|c|}{$\begin{array}{l}\text { Aspects that could shape the } \\
\text { ethical climate perception }\end{array}$}} & \multicolumn{5}{|c|}{ ETHICAL CLIMATE TYPES (M) } \\
\hline & & \multirow{2}{*}{$\begin{array}{l}\text { Law } \\
\text { and } \\
\text { care }\end{array}$} & \multirow{2}{*}{$\begin{array}{l}\text { Adhering } \\
\text { the law, } \\
\text { procedures } \\
\text { and rules }\end{array}$} & \multirow[t]{2}{*}{$\begin{array}{c}\text { Organizational } \\
\text { interest }\end{array}$} & \multirow{2}{*}{$\begin{array}{l}\begin{array}{c}\text { Team } \\
\text { spirit } \\
\text { and }\end{array} \\
\text { personal } \\
\text { morality } \\
2.70\end{array}$} & \multirow[t]{2}{*}{$\begin{array}{c}\text { Personal } \\
\text { interest }\end{array}$} \\
\hline \multirow{7}{*}{$\begin{array}{c}\text { Sense of } \\
\text { belonging } \\
(\mathrm{M}=3.95)\end{array}$} & Never (1) & & & & & \\
\hline & Rarely (2) & & & & 3.34 & \\
\hline & Sometimes (3) & & & & 3.66 & \\
\hline & Often (4) & & & & 3.90 & \\
\hline & Always (5) & & & & 4.13 & \\
\hline & Fvalue & & & & 4.16 & \\
\hline & Significance & & & & .04 & \\
\hline \multirow{7}{*}{$\begin{array}{l}\text { Good } \\
\text { interpersonal } \\
\text { relations } \\
(\mathrm{M}=3.16)\end{array}$} & Never (1) & & & & & 4.33 \\
\hline & Rarely (2) & & & & & 4.10 \\
\hline & Sometimes (3) & & & & & 3.92 \\
\hline & Often (4) & & & & & 3.65 \\
\hline & Always (5) & & & & & 3.97 \\
\hline & Fvalue & & & & & 5.59 \\
\hline & Significance & & & & & .02 \\
\hline
\end{tabular}


ToSEE - Tourism in Southern and Eastern Europe, Vol. 5, pp. 441-455, 2019 M. Mijatov, A. S. Dragin, A. Badurina: INDIVIDUAL VALUES, EMPLOYMENT ...

\begin{tabular}{|c|c|c|c|c|c|c|}
\hline \multirow{2}{*}{\multicolumn{2}{|c|}{$\begin{array}{l}\text { Aspects that could shape the } \\
\text { ethical climate perception }\end{array}$}} & \multicolumn{5}{|c|}{ ETHICAL CLIMATE TYPES (M) } \\
\hline & & \multirow{2}{*}{$\begin{array}{l}\text { Law } \\
\text { and } \\
\text { care }\end{array}$} & \multirow{2}{*}{$\begin{array}{l}\begin{array}{l}\text { Adhering } \\
\text { the law, } \\
\text { procedures } \\
\text { and rules }\end{array} \\
4.67\end{array}$} & \multirow{2}{*}{$\begin{array}{c}\text { Organizational } \\
\text { interest }\end{array}$} & \multirow{2}{*}{$\begin{array}{l}\text { Team } \\
\text { spirit } \\
\text { and } \\
\text { personal } \\
\text { morality }\end{array}$} & \multirow{2}{*}{$\begin{array}{c}\text { Personal } \\
\text { interest }\end{array}$} \\
\hline \multirow{7}{*}{$\begin{array}{c}\text { Self- } \\
\text { fulfilment } \\
(\mathrm{M}=4.18)\end{array}$} & Never (1) & & & & & \\
\hline & Rarely (2) & & 3.98 & & & \\
\hline & Sometimes (3) & & 4.25 & & & \\
\hline & Often (4) & & 4.35 & & & \\
\hline & Always (5) & & 4.53 & & & \\
\hline & $F$ value & & 4.02 & & & \\
\hline & Significance & & .05 & & & \\
\hline \multirow{7}{*}{$\begin{array}{c}\text { Being well } \\
\text { respected } \\
(\mathrm{M}=4.34)\end{array}$} & Never (1) & & & 4.25 & & \\
\hline & Rarely (2) & & & 3.60 & & \\
\hline & Sometimes (3) & & & 3.66 & & \\
\hline & Often (4) & & & 3.63 & & \\
\hline & Always (5) & & & 3.60 & & \\
\hline & $F$ value & & & 7.88 & & \\
\hline & Significance & & & .01 & & \\
\hline
\end{tabular}

Source: Research results

The research results of t-test conducted in order to determine the differences in the employees' perception of the ethical climate, based on the fact whether the employees work within Kopaonik throughout the year or during the winter season, did not indicate the existence of significant differences. However, results of the single-factor univariate analysis indicated that there are significant differences in perception of Adhering the law, procedures and rules $(F=3.997 ; p<0.01)$ and Organizational interest $(F=3.278 ; p<$ $0.05)$ based on the working status of the respondents.

It could be said that there is significant difference between the employees' perception of Adhering the law, procedures and rules between the half-time employees and students in practise (Chart 1). On the basis of the research results, it could be noted that perception of this ethical climate type is stronger among the half-time employees compared to students in practice. Also, significant difference in perception of Adhering the law, procedures and rules exists between students in practice and full-time employees, whose perception of this ethical climate type is also stronger compared to perceptions of the same ethical climate type among the students. 
ToSEE - Tourism in Southern and Eastern Europe, Vol. 5, pp. 441-455, 2019

M. Mijatov, A. S. Dragin, A. Badurina: INDIVIDUAL VALUES, EMPLOYMENT ...

Chart 1: Working status and Adhering the law, procedures and rules $(F=3.997 ; p<0.01)$

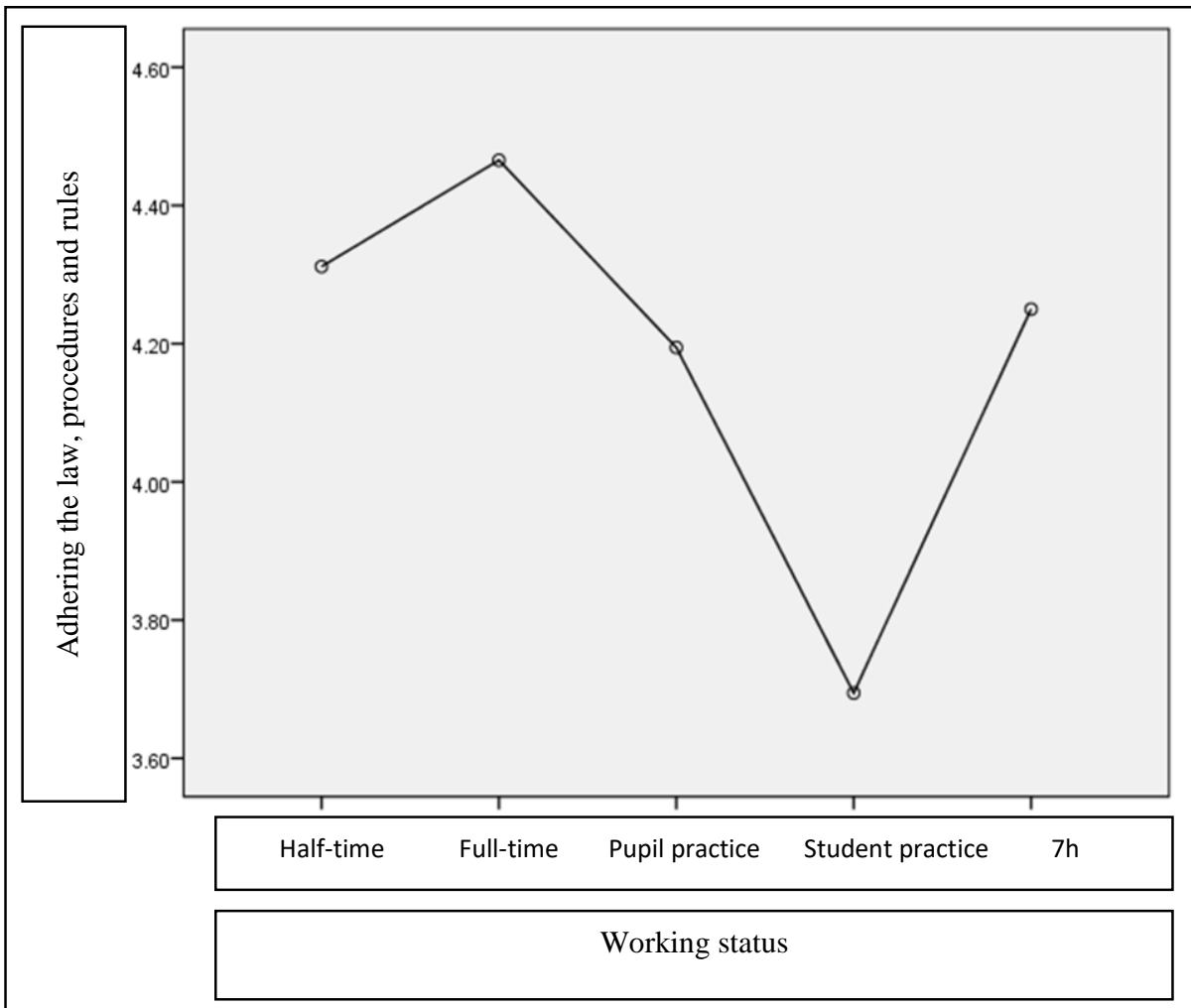

Source: Research results

Significant differences are also identified in perception of Organizational interest based on the current working status of the employees. Based on the research results (Chart 2), it could be seen that perception of Organizational interest of the full-time employees is significantly different from perception of the same ethical climate type among the pupils and students in practice. The research results also showed that there is significant difference between the pupils and students in practice, so perception of Organizational interest is lower among the students compared to the pupils. 
ToSEE - Tourism in Southern and Eastern Europe, Vol. 5, pp. 441-455, 2019

M. Mijatov, A. S. Dragin, A. Badurina: INDIVIDUAL VALUES, EMPLOYMENT ...

Chart 2: Working status and Organizational interest $(F=3,278 ; p<0,05)$

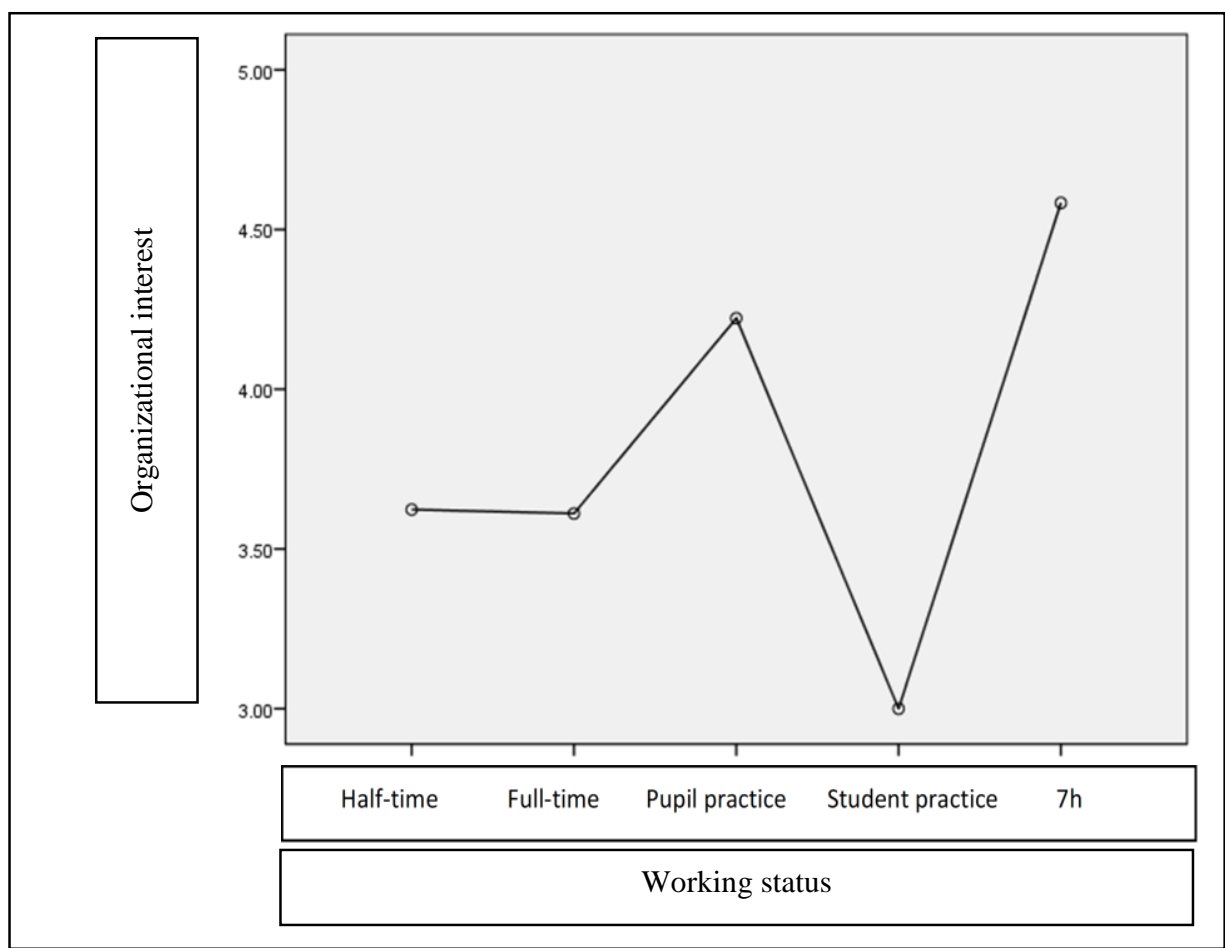

Source: Research results

In terms of length of working tenure, a single-factor univariate analysis of the variance showed that significant difference exists only in the case of the employees' perception of Law and care $(F=2.650 ; p<0.05)$. Thus, it could be seen that there is significant difference in perception of Law and care among the employees with less than five years of working tenure and those working between 16 and 20 years. Perception of Law and care is more pronounced among the employees who have between 16 and 20 years of working tenure compared to the employees with up to five years of work experience. Employees who work between 16 and 20 years also have significantly higher perception of Law and care in comparison to the employees who work between six and ten years (Chart 3). This difference is the most pronounced, but it could also be seen that perception of Law and the care among the group of the respondents who have between 16 and 20 years of working tenure is generally different and it could be said that is higher comparing to all of the other groups. However, group of the respondents with more than 21 years of working tenure is not so represented in the hotels located in Kopaonik, compared to the younger group of the respondents with shorter working experience. It is, therefore, essential to pay attention to differences in perception of stated ethical climate type among the employees who have between 16 and 20 years of working tenure and those with shorter working experience. 
ToSEE - Tourism in Southern and Eastern Europe, Vol. 5, pp. 441-455, 2019

M. Mijatov, A. S. Dragin, A. Badurina: INDIVIDUAL VALUES, EMPLOYMENT ...

Chart 3: Working tenure and Law and care $(F=2.650 ; p<0.05)$

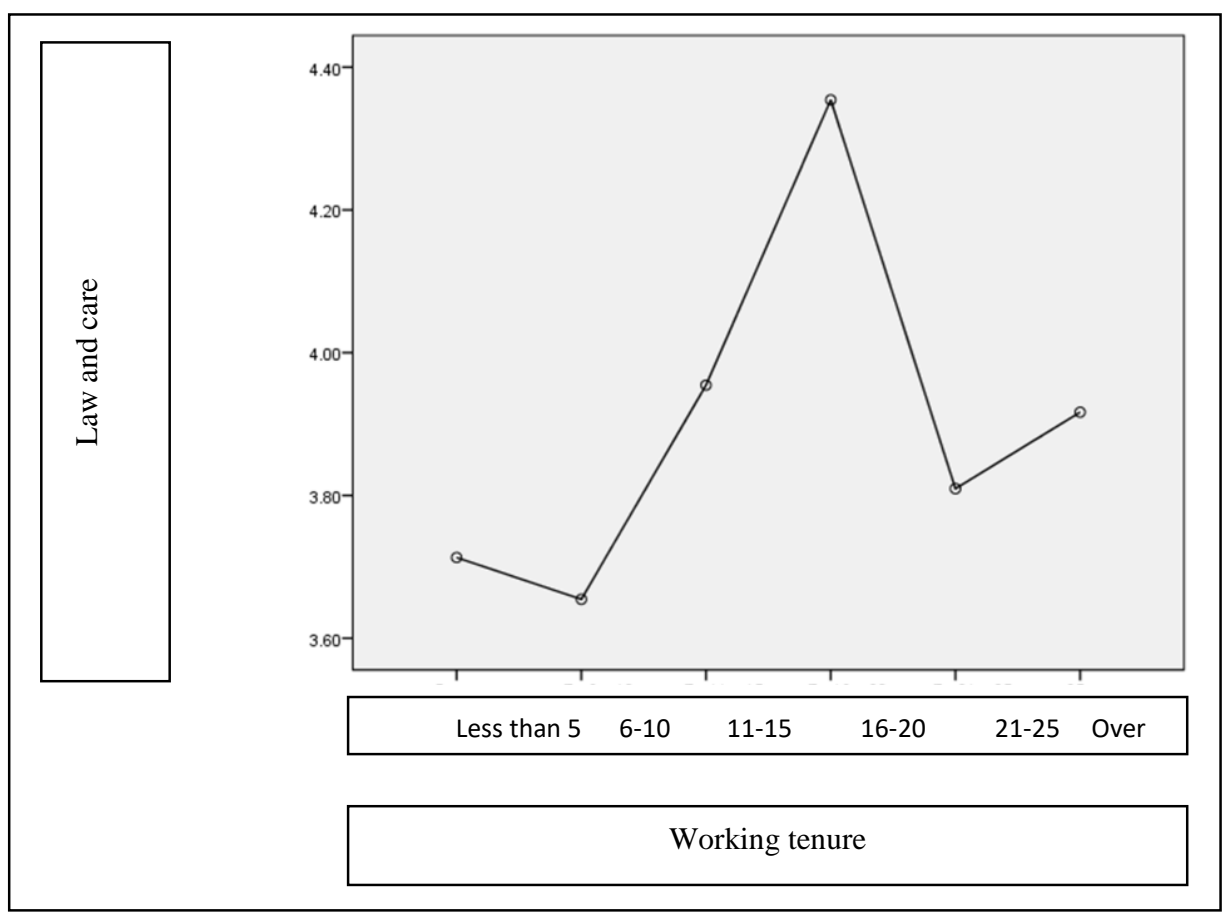

Source: Research results

\section{DISCUSSION AND CONCLUSION}

In the case of the List of values, (Kahle 1983), only four out of nine individual values shaped the perception of certain ethical climate types among the employees in hotels of Kopaonik. Thus, increase of the employees' sense of belonging increases their perception of Team spirit and personal morality. Employees with high sense of belonging will work to ensure the well-being of all members within the group. In this case, it is a working group, where sense of belonging with colleagues could be important, because they spend a lot of time in the workplace. Also, specificity of the business in the field of hospitality requires close co-operation of the employees, which is the main reason why it is not surprising that sense of belonging might shape their perception of Team spirt and personal morality in a positive manner. On the other hand, employees with lower sense of belonging could do something that will harm the working group. Thus, degree of importance of good interpersonal relations shapes the employees' perception of Personal interest, in the way that the strongest perception of Personal interest is shown by the employees who do not care for the others too much. The lowest perception of this empirical type of the ethical climate, on the other hand, is identifies among the employees who consider that good interpersonal relationship is important. In general, it could be concluded that perception of Personal interest is decreasing along with an increase of importance of good interpersonal relations. 
ToSEE - Tourism in Southern and Eastern Europe, Vol. 5, pp. 441-455, 2019

M. Mijatov, A. S. Dragin, A. Badurina: INDIVIDUAL VALUES, EMPLOYMENT ...

Furthermore, self-fulfilment shapes the employees' perception of Adhering the law, procedures and rules. The research results showed that perception of this ethical climate type is decreasing among the employees who stated that sense of self-fulfilment is not so important, opposite to those who consider this sense as important. Thus, general impression is that those who consider the self-fulfilment as important, perceive that they are expected to abide by prescribed laws, procedures and rules, because, in that way, they could gain the opportunity to progress in the organization. On the other hand, even those employees whose sense of self-fulfilment is not so expressed are expected to abide by the prescribed laws, procedures and rules, which does not mean that they will necessarily follow the prescribed rules.

The last individual value with significant influence on shaping the employees' perception of the ethical climate among the employees in hotels of Kopaonik is their need for being well respected. This individual value shapes the employees' perception of Organizational interest. The highest perception of this ethical climate type is identified among the employees who consider that stated individual value is not so important, while it is the lowest among the employees who always consider that it is important to be well respected. Organizational interests are often oriented towards improving the business performances, regardless the other considerations. Those who strictly strive to promote the organizational interests could do something that might harm their colleagues, which could result in losing their respect and vice versa.

Beside the individual values, this research was oriented towards selected characteristics of the employment (such as seasonal or the whole-year employment, working status, years of the working tenure). It is interesting that differences in whether the employees of hotels in Kopaonik work during the winter season or seasonally did not cause the differences in perception of identified ethical climate types. On the other hand, the working status of the respondents pointed to differences in perception of Adhering the law, procedures and rules and Organizational interest. Thus, full-time and part-time employees showed stronger perception of Adhering the law, procedures and rules in comparison with students in practice. Students are still learning on their duties and responsibilities throughout the practice, so management could tolerate their mistakes. This is in line with the statement of Tilly (Tilly 1992) who indicated that it is necessary to consider the status of employment when insisting on a certain level of ability and knowledge regarding the rules and business procedures. On the other hand, full-time employees are expected to be familiar with all laws, procedures and business rules.

Perception of Organizational interest is also stronger among the full-time employees comparing to students in practice. However, it is surprising that perception of Organizational interest is lower among the students compared to the pupils. This finding might be a consequence of the fact that pupils from the vicinity of Kopaonik want to work in these hotels, after finishing the high school. Pupils in practice are usually from the surrounding cities and they are under the frequent supervision of their professors, comparing to students on a longer distance from their Faculties.

Finally, this research also showed that perception of Law and care is stronger among the employees with longer working experience. The research results of this study are in accordance with findings of Kim and Miller (2008), who also indicated that employees 
ToSEE - Tourism in Southern and Eastern Europe, Vol. 5, pp. 441-455, 2019

M. Mijatov, A. S. Dragin, A. Badurina: INDIVIDUAL VALUES, EMPLOYMENT ...

with short working experience show lower perception of the ethical climate related to the compliance with prescribed laws and codes, comparing to perception of the employees with longer working experience.

All of these findings should be considered integrally, due to the fact that they could be a basis for the management when creating the general organizational climate, including the ethical climate. Thus, the awareness on the employees' individual values, together with providing the adequate conditions related to their employment, could encourage the positive ethical climate within the organization, while, in opposite, it could cause various negative outcomes for general business performances.

\section{ACKNOWLEDGEMENT}

This research is a part of the project approved by the Ministry of Education, Science and Technological Development (registration number: 176020 OI), as well as the project approved by the Autonomous Province of Vojvodina, Republic of Serbia, Provincial Secretariat for Higher Education and Scientific Research (Program 0201, number of the project 114-451-2080/2016-01).

\section{REFERENCES}

Aquino, K. and Reed, I.I. (2002), "The self-importance of moral identity", Journal of Personality and Social Psychology, Vol. 83, pp. 1423-1440.

Authors (Under the Review Process), "Identification of predictors' effects on perceiving the ethical climate and job satisfaction within Serbian tourism industry".

Authors (2019), "Types and factors of ethical climate perception in Serbian tourism industry", Journal of East European Management Studies, Special Issue (February), pp. 63-98.

Authors (In Press), "Perception of the ethical climate within the hotel business according to the employees' socio-demographic characteristics", in $3^{\text {rd }}$ International thematic monograph, Modern Management and Economy of Tourism Sector in Present Era, In Editing.

Bergman, R. (2002), "Why be moral? A conceptual model from developmental psychology", Human Development, Vol. 45, pp. 104-124.

Brown, M.E. and Treviño, L.K. (2006), "Ethical leadership: A review and future directions", The Leadership Quarterly, Vol. 17, pp. 595-616.

Brown, M.E., Treviño, L.K. and Harrison, D.A. (2005), "Ethical leadership: A social learning theory perspective for construct development", Organizational Behavior and Human Decision Processes Vol. 97, pp. 117-134.

Cullen, J.B., Praveen, P. and Victor, B. (2003), "The effects of ethical climates on organizational commitment: A two-study analysis", Journal of Business Ethics, Vol. 46, pp. 127-141.

Elci, M. and Alpkan, L. (2009), "The impact of perceived organizational ethical climate on work satisfaction", Journal of Business Ethics, Vol. 84, pp. 297-311.

Huimin, G. and Ryan, C. (2011), "Ethics and corporate social responsibility - An analysis of the views of Chinese hotel managers", International Journal of Hospitality Management, Vol. 30, pp. 875-885.

Jolliffe, L. and Farnsworth, R. (2003), "Seasonality in tourism employment: Human resource challenges", International Journal of Contemporary Hospitality Management, Vol. 15, No. 6, pp. 312-316.

Kahle, L.R. (1983), "Social values and social change: Adaptation to life in America", Praeger, New York.

Kim, N.Y. and Miller, G. (2008), "Perceptions of the ethical climate in the Korean tourism industry", Journal of Business Ethics, Vol. 82, No. 4, pp. 941-954.

Koh, H.C. and Boo, E.H.Y. (2001), "The link between organizational ethics and job satisfaction: A study of managers in Singapore", Journal of Business Ethics, Vol. 29, pp. 309-324.

Lee, L.Y.S. and Tsang, N.K. (2013), "Perceptions of tourism and hotel management students on ethics in the workplace", Journal of Teaching in Travel \& Tourism, Vol. 13, No. 3, pp. 228-250. 
ToSEE - Tourism in Southern and Eastern Europe, Vol. 5, pp. 441-455, 2019

M. Mijatov, A. S. Dragin, A. Badurina: INDIVIDUAL VALUES, EMPLOYMENT ...

Lee, Y.K., Kim, S.H., Banks, H.S.C. and Lee, K.H. (2015), "An ethical work climate and its consequences among food-service franchise employees", Asia Pacific Journal of Tourism Research, Vol. 20, No. 11 , pp. 1286-1312.

Lucas, N.J. (2000), "Lives of integrity: Factors that influence moral transforming leaders", Dissertation Abstracts International Section A: Humanities \& Social Sciences, Vol. 60, pp. 32-89.

Luria, G. and Yagil, D. (2008), "Procedural justice, ethical climate and service outcomes in restaurants", International Journal of Hospitality Management, Vol. 27, pp. 276-283.

McCuddy, M., Pinar, M. and Birkan, I. (2010), "Gender bias in managing human resources in the Turkish hospitality industry: Is bias impacted by demographic context? ", Proceedings of ASBBS, Vol. 17, No. 1, pp. 479-493.

Nasir, N.A. and Kirshner, B. (2003), "The cultural construction of moral and civic identities", Applied Developmental Science, Vol. 7, pp. 138-147.

Petrick, J.A. and Quinn, J.F. (2001), "The challenge of leadership accountability for integrity capacity as a strategic asset", Journal of Business Ethics, Vol. 34, pp. 331-343.

Pinar, M., McCuddy, M., Birkan and I., Kozak, M. (2011), "Gender diversity in the hospitality industry: An empirical study in Turkey", International Journal of Hospitality Management, Vol. 30, pp. 73-81.

Quazi, A.M. (2003), "Identifying the determinants of corporate manger's perceived social obligations", Management Decision, Vol. 41, No. 9, pp. 822-831.

Schminke, M., Ambrose, M.L. and Neubaum, D.O. (2005), "The effect of leader moral development on ethical climate and employee attitudes", Organizational Behavior and Human Decision Processes, Vol. 97, pp. 135-151.

Schneider, B., Bowen, D.E., Holcombe, K.M. and Ehrhart, M.E. (2000), "The climate for service: Evolution of a construct", in Ashkanasy, N.M., Wilderom, C. and Peterson M.F. (eds.), Handbook of organizational culture and climate, Sage, Thousand Oaks, CA

Schulte, M., Ostroff, C. and Kinicki, A.J. (2006), "Organizational climate systems and psychological climate perceptions: A crosslevel study of climate-satisfaction relationships", Journal of Occupational and Organizational Psychology, Vol. 79, pp. 645-671.

Schwartz, M. (2001), "The nature of the relationship between corporate codes of ethics and behaviour", Journal of Business Ethics, Vol. 32, No. 3, pp. 247-262.

Tilly, C. (1992), "Dualism in part-time employee", Industrial Relations, Vol. 31, pp. 330-347.

Treviño, L.K., Brown, M. and Hartman, L.P. (2003), "A qualitative investigation of perceived executive ethical leadership: Perceptions from inside and outside the executive suite, Human Relations, Vol. 56, pp. 5-37.

Victor, B. and Cullen, J.B. (1987), "A theory and measure of ethical climate in organizations", in Frederick, W.C. (Ed.), Research in corporate social performance), JAI Press, Greenwich, CT, pp. 57-71.

Victor, B. and Cullen, J.B. (1988), "The organizational bases of ethical work climates", Administrative Science Quarterly, Vol. 33, pp. 101-125.

Weeks, W.A., Leo, T.W., Chonko, L.B. and Wakefield, K. (2004), "The effect of perceived ethical climate on the search for sales force excellence", Journal of Personal Selling \& Sales Management, Vol. 24, pp. 199-214.

Zoghbi-Manrique-de-Lara, P. and Guerra-Baez, R. (2016), "Exploring the influence of ethical climate on employee compassion in the hospitality industry", Journal of Business Ethics, Vol. 133, No. 3 , pp.605-617. 
ToSEE - Tourism in Southern and Eastern Europe, Vol. 5, pp. 441-455, 2019

M. Mijatov, A. S. Dragin, A. Badurina: INDIVIDUAL VALUES, EMPLOYMENT ...

Maja Mijatov, PhD, Research Associate

University of Novi Sad

Faculty of Sciences

Department of Geography, Tourism and Hotel Management

Trg Dositeja Obradovića 3, Novi Sad, Serbia

Phone: +281642036990

E-mail:majamijatov@gmail.com; majam@dgt.uns.ac.rs

Aleksandra S. Dragin, PhD, Full Professor

University of Novi Sad

Faculty of Sciences

Department of Geography, Tourism and Hotel Management

Trg Dositeja Obradovića 3, Novi Sad, Serbia

E-mail: sadragin@gmail.com; aleksandra.dragin@dgt.uns.ac.rs

Antonio Badurina, $\mathrm{PhD}$ Student

University of Rijeka

Faculty of Tourism and Hospitality Management

Primorska 42, P.O.Box 97, 51410 Opatija, Croatia

E-mail: antonio.badurina@gmail.com 